\title{
ナノカーボンの電子状態計算入門
}

\author{
齋藤理一郎*
}

(平成15年4月8日受理, 平成15年4月14日採択)

\section{Introduction to Electronic Structure Calculation of Nano-Carbon}

\begin{abstract}
Riichiro Saito ${ }^{*}$
We introduce some calculation methods for structure and electronic structure of various carbon materials. Some experimental spectra of Raman spectroscopy, infrared absorption, STS and STM can be directly compared with the calculated results.
\end{abstract}

KEYWORDS : Nano-carbon, Structual optimization, Linux, Mopac, Gaussian, Tersoff potential, Density of states

\section{1. 序 論}

\section{1 本稿のねらい}

計算機の進歩とともに, 実験と理論の間の垣根が日をおう ごとに低くなってきた。理論は, 実験に精通していなければ 計算ができない。また実験をやりながら計算を行い, その場 で考察する時代がきたといえる。

とはいっても現実はそうたやすくない。計算を理論家に頼 むにはちょっと気が重いし，なかなかやってくれない。そう かといって自分で計算するのも大変そうた，と考えている方 は多いのではないか？簡単に計算できたらなあ, という希 望にお答えするのが本稿のねらいである。もちろん対象を無 節操に広げるのは適当ではない。具体的な本稿の内容を以下 に限定する。

（1）学部4年生が 1 年間, 卒業研究で理論計算をしてできるこ と (大学院修士なら 半年, 博士なら1〜2力月ぐらい)。

（2）必要な機材がパソコンぐらいであり, 基本的に無償のソ フトウエアを使うこと (有償のソフトウエアでなければ できないものは, その都度注を入れる)。入手方法も含め, すべて自分でできること。

（3）計算結果をどういうふうに使うべきであるか？を判断 できること。

もちろん本当に計算をする場合には何らかのアドバイスが 必要であるが, それは非常に些細なことであり, 質問には個別 にお答えしたい。理論計算を使うことが, 理論計算を理解す る最良の方法であると思っている。

\section{2 理論計算の必要性}

従来, 炭素材料はマクロな視点でとらえられていた。形状 や表面積, 欠陥とか計算で実験をシミュレーションすること はできるが, 電子状態との関連を議論することは稀であった。

しかし最近のナノカーボンの世界は, 扱っている原子数が 100〜1000程度であり, 分子の形に直接関係した特異な物性 が, 分子の電子状態から説明できる。理論計算によって新規 現象に対する新しい知見を得たり，実験に対して指針を与え ることが普通である。理論が実験に非常に接近した世界とい える。したがって実験だけ，計算だけ，ではこのおもしろいナ ノの世界を開拓できない。

電子状態計算は本来, 理論家の仕事であった。ところが計 算機が進歩したおかげで, 原子数が100〜1000程度のナノメー トルの大きさの炭素物質を, パソコンでも十分計算できるよ うになった。ソフトウエアもインターネットを通じて手に入 れることができる。

問題は考える形の種類が指数関数的に増えたので, 理論家 だけでは実験のすべてを説明するだけの時間がなくなったこ とである。また現象をいち早く理解し実験の研究スピードを あげるためには，どうしても身近なところに計算する人間 (環 境) が必要であることである。理論計算をすることによって, 実験に新しいアイデアをもたらすことが常に実験の現場で行 われなければならないと考えている。

\section{2. 計算をするのに必要なもの}

まず実際にやってみようという人のため, 何が必要かを書

- Corresponding Author, E-mail: saito-win@cmpt.phys.tohoku.ac.jp 東北大学大学院理学研究科物理学専攻, CREST JST : T980-8578 仙台市青葉区荒巻字青葉 Department of Physics, Tohoku University and CREST JST : Aoba-ku, Sendai 980-8578, Japan 
く。少しコンピュータ用語が多いので, 単に読んでいる方は 次の章に飛んでも差し支えない。

\section{1 パソコンとLinux}

計算をする場合には，まずパソコンが必要である。性能は 計算時間との兼ね合いなので, 新規購入する必要はない。簡 単な計算結果を得てから, 新しい機械を購入すべきである。 すべて『何かがないからできない』ということはない。ある ものでまず工夫することは，どんな場合にでも教育的である。

多くの無償のソフトウエアは,ソースコード (プログラム言 語で書かれたもの) で与えられる。実行させるにはコンパイ ラー(ソースコードを機械語に変換するもの), ライブラリー (行列計算など数学的な演算をするできあいのプログラム集) を調達すればよい。このソフトウエアを適当なOS（オペレー ティングシステム, 計算機を動かす基本ソフト。Windowsも OSの1つ) 上で動かす。

無償ソフトウエアではOSとしてLinuxが便利である。 Windowsパソコンとしても使う場合にはハードディスクの 一部分 (3GB以上) をLinux用に確保し, 起動時にOSを選択し て使う（partitionを切り直す有償のソフトウエアとしては partition magicがある。無償でもfips.exeなどがLinuxにある)。 LinuxのOSのインストールは自動化されている。さらにOS 自体もネットワーク上から無償でダウンロードできる。代表 的なLinuxの種類としてRed Hat, Vineがある。これらは, ネッ トワーク上の検索エンジンを使えばみつかる。

あえてここで関連Webサイトを示さないのは, 情報が古く なってその都度訂正しなければならないことを恐れるからで ある。検索で探すことによって新たな発見もあるので, 情報 をうまく取り込むことを期待したい。

\section{2 コンパイラー, ライブラリー}

プログラムを作る場合には, プログラム言語のコンパイラ 一が必要である。代表的なプログラム言語としてFortran言 語, C言語があるが, Linuxの場合には, それぞれg77, gccとい う無償のコンパイラーが用意されている。また大学の研究機 関であれば, インテルが同社のCPU (中央演算装置) の最大の 性能を引き出すように作ったコンパイラーとそのマニュアル が無償で手に入る。インテルのコンパイラーの効果は, 無視 できないほど大きいので導入を勧めるが, 多くの無償のソフ トウエアはgccなどを使うことが前提になっているので, コン パイラーの固有な部分の (内部関数呼び出しなどの) ソース コードを一部変更する作業が必要になる。

いろいろな『だんどり』が必要な設定作業では, 手順が重要 である。事前に設定を細かく考えれば動作環境は快適になる が, 最終的に動くまでに時間がかかる。努力しても結局使わな いことも考えられる。まずは動かすことを最優先にして, 改善 すべきことは動いた後にできるようにメモしておくとよい。 将来のために設定記録をコンピュータ上に残しながら進める のが必須である。計算が繰り返し利用されるようになったら,
速く容易に処理するための動作環境を整備すべきである。

プログラムで使う行列計算, 関数計算のためのライブラリ 一は, 自分で作る必要はない。Lapackと呼ばれる線形計算用 ライブラリーがソースから無償で提供されている。多くの利 用者もいて実績があるので扸めする。Lapackを動かすには Brasという基本ライブラリーも同時に必要である。丸善から 『LAPACK利用の手引き』(小国力訳)という本が出ている。

\section{3 グラフィック}

XY形式の二次元のグラフを書くのであれば, Linux上で動 く無償のxmgrace (またはxmgr) をお勧めする。われわれの研 究グループはこの10年, これを用いて論文の図を書いている。 三次元のグラフはWindows上では多くあるのでそれを使うの がよい。ただし有償である。もしこれもLinux上で行うのな らMESAと呼ばれるOpenGL互換の無償のライブラリーで自 作できる。インストールしてデモプログラムを動かせば, 機 能を知ることができる。しかしMESAを使うには, 熟練が必 要である。簡単な図を書く場合, 昔はBasicを使っていた。現 在はVisual系のC言語やBasic, またTcl/Tk 言語が容易である。 実験装置, 計算を駆動させるパネルなどを作るときに大変重 宝する。

\section{3. 実際の計算}

計算機環境がそろったところで, 何か実際に計算をしてみ たいところである。プログラムを書くのは大変なので, まず はできあいのソフトウエアを使ってみるのがよいと思われ る。しかしグラファイトは若干特殊であり,できあい計算で の再現が難しい問題がある。炭素特有の問題については後半 に述べる。

\section{1 構造最適化の手法}

電子状態計算や物理化学的な諸量は, 最安定な構造で計算 する必要がある。構造最適化とは, 与えられた分子構造を最 安定な (最も全エネルギーの小さい) 構造にすることである。 分子の場合には, 一般に量子化学計算と呼ばれるプログラム で構造最適化を実行する。この場合, ハートリーフォック計 算 $(\mathrm{HF})$ を行い, 計算した分子の全エネルギーが最小になるよ うに原子の位置を少しずつ動かすものである。電子状態も同 時に求まる。

この場合, 原子間のポテンシャルを, 実在する分子の結果を 再現するように経験的に与えてHF計算を行う半経験的手法 と, 非経験的に定める ab initio (アプ・イニシオ) 計算がある。 前者で有名なのがMopacであり, 後者で有名なのがGaussian98 (Gaussian03が最新) である。

Mopacはver.7までは, 無償ソフトウエアであり, その後は有 償のソフトウエアである。有償のソフトウエアはWindows上 でも動き, 可視化 (WinMopac) されてかなり使いやすくなっ ている (Fig.1 (a) 参照)。無償でも可視化されたものがイン ターネット上で公開されている (mopacで検索をかけると出 
(a)

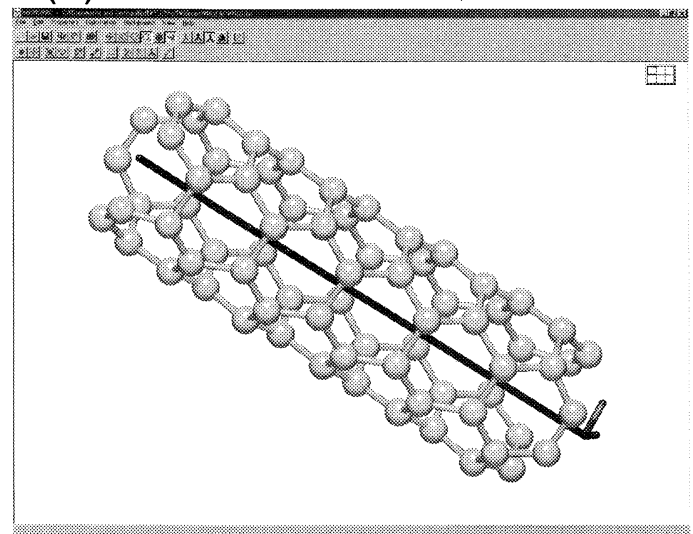

(b)

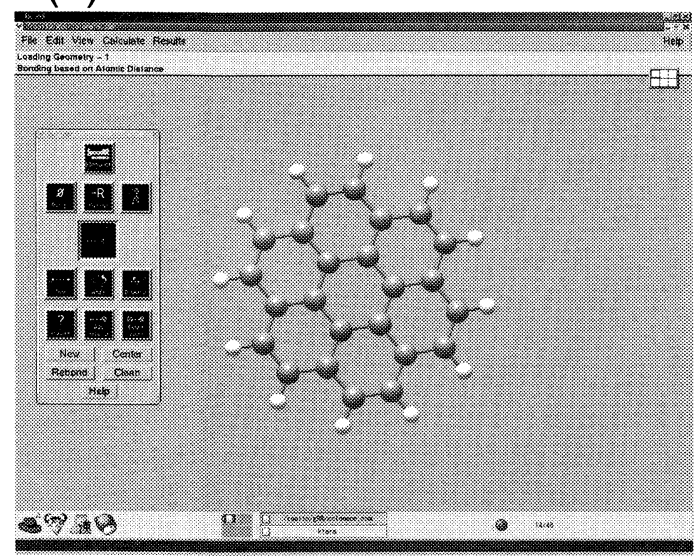

Fig.1 (a) WinMopac (mopac) and (b) GaussView (Gaussian98). The quantum chemistry calculations can be done by designing a molecule on the screen of PC. Some physical properties can be calculated by specifying keywords in the panel.

てくる)。筆者は利用していないが試したことはある。半経 験的手法は, 最外殼の電子のみ扱うので計算時間が非経験的 な計算に比べて短く簡単である。Mopacに関しては,『分子軌 道法MOPACガイドブック』(平野恒夫, 田辺和俊編, 海文堂) の参考書があり, 独習できる。

Mopacの計算では満足いかないのであれば, Gaussian98な どガウス型軌道を用いたab initio計算をお勧めする。基本的 に有償でありマニュアルもある。多くの計算機センターにあ るので利用するのが簡単である。

Linux上の実行ファイルのサイトライセンス (学内で自由 に利用）を共同で購入するなら実用価值がある。GaussView などの画面上で処理するものは操作が簡単なので, 学生実験 の項目として導入できる (Fig.1 (b) 参照)。Gaussian98でも, パラメーターを選ぶことで半経験的計算も行うことができ る。さまざまな計算機能があるので, 使いなれるまで時間が かかるが, 結果に再現性がある点で利用価值が高い。
もちろんWinMopacやGaussViewの可視部分がなくても実 行には問題ない。実際，なれてくると分子構造はxmol, xmm と呼ばれる無償のソフトウエアで確認して直接実行プログラ ムを動かす。このほうが若干であるがインターフェース部分 を介さないので速度が速い。

\section{2 構造最適化で得られるもの}

Mopacは, 構造最適化した原子間の距離や結合角などの構 造パラメータをよく再現する。不純物や端がある場合の原子 クラスターなどの欠陥の状態を，定量的にみることができる。 Gaussianは, どのような基底関数 (計算に用いるガウス型関数 の集まり)を選ぶかによって精度が異なる。一般に変分計算 であるので, 基底関数の数を増やすと結果はよくなる。計算 時間も増えるのでまずは簡単なものから試すのがよい。

いずれの場合にでも, 結果の值を無批判に使ってはならな い。結果が妥当であるか, 既知の実験值と比べ判断する必要 がある。またよくわかっている分子を比較のため計算する ことが必須である。実験で対照実験が必要なように, 計算に も必ず対照計算が必要である。さらに実験值から系統的なず れがある場合には，計算結果を補正して使うことも場合によ って必要である。

\section{3 グラファイトの面間隔}

量子化学計算は多くの分子で利用でき完成度が高い。しか しグラファイトでは, グラファイトの面間隔 (3.5A) を再現す ることはできない問題点がある。 $3.5 \AA$ という距離は, イオン 結合のような静電的な力では十分到達する距離であるが, 共有 結合のような波動関数の広がりによる力に対しては長すぎる。

経験的にグラファイトの面間隔を再現する炭素間ポテンシ ヤルとして, $(6,12)$ van der Waarlsポテンシャル

$$
U(R)=4 \varepsilon\left\{-\left(\frac{\sigma}{r}\right)^{6}+\left(\frac{\sigma}{r}\right)^{12}\right\} .
$$

が使われる。ここで, Luによる1),2) パラメータ $\sigma=3.407[\AA]$, $\varepsilon=2.968[\mathrm{meV}]$ を用いると,グラフファイト結晶 (AB staking)

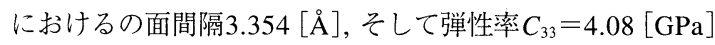
を再現する。

このポテンシャルの計算は, $1 / r^{6}$ で急速に減少するが, 計算 の速度を上げるために $17.5 \AA$ ڤ上上の距離に対してはポテンシ ヤルを0にしている（カットオフという）。このカットオフ長 はグラファイト層5層分になる。 $\mathrm{AB}$ スタッキング構造をとっ て層の数を1層ずつ増やしていくと, 層間の間隔が $3.45 \AA$ から $3.35 \AA ̊$ に単調に減少する。実験事実をよく再現するポテンシ ヤルといえる。

\subsection{Tersoffポテンシャル}

van der Waarlsポテンシャルを計算に入れるためには, 自分 で構造を最適化するプログラムを作る必要がある。炭素の $\mathrm{sp}^{3}, \mathrm{sp}^{2}$ の共有結合を再現する炭素原子間ポテンシャルとして, Tersoffポテンシャルが知られている31,4)。このポテンシャル 
は結合角に関連する3体のポテンシャルを巧妙に原子間の2体 のポテンシャルに組み込むことによって計算時間がかからな いように工夫されている。グラファイト1層の構造, ダイヤモ ンド, $\mathrm{C}_{60}$ などの構造を再現することが知られている。

Tersoffポテンシャルのカットオフ長を $2.5 \AA$ にして, $2.5 \AA ̊ 2$

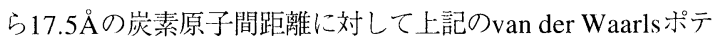
ンシャルを使うと炭素クラスターの構造を再現できる5)。

ただしTersoffポテンシャルは,もともとダイヤモンドをより よく再現するために作られているので, $\mathrm{C}_{60}$ の原子間距離は実験 事実より少し大きめに出ることが知られている。したがって, 計算結果に0.9685のfactorをかけると実験事実を再現する5。

\section{5 共役勾配法と分子動力学法}

実際に全エネルギーを最小にする手法として, 共役勾配法 と分子動力学法がある。与えられたポテンシャル曲面から工 ネルギー最小点の方向を決める数学的手法が共役勾配法であ る。ある方向に進み極小になったら，今まで進んできた方向 に直角な方向に進めというのが, 荒っぽい共役勾配法の説明 である。ポテンシャルの形が, $\mathrm{N}$ 個の座標の二次関数で書かれ る場合には, Nステップの探査でN次元空間で最小值に到達す る。実際には, ポテンシャルの形は複雑なので有効に働かな い場合もある。例えばナノチューブのように細長い場合には， 中心部の原子は左右両側から力を受けるので, 最初は動かな い。原子間距離の補正がナノチューブの端から順に起こるの で, 最小化まで時間がかかる問題がある。

これに対し, 原子にランダムに運動エネルギーを与えて運 動させ, 次に温度を下げる (各原子の速度を減速させる) こと で最小点にもっていく物理的な手法を分子動力学法と呼ぶ。 分子動力学法の利点はすべての原子に同時に補正が㗢くので 端があるような分子で原子数の多い場合には有効である。計 算も理解しやすい。欠点は, 温度の下げ方は系によっては準 安定な点に捕まってしまう場合もあることである。

いずれの場合にもいえることであるが, 試行錯誤をして結 果を比較することが正しい結果を得る最短の方法である。自 分が『正解の野原』にいるか，『見当違いの崖っぷち』に立って いるかは, 足もとをみただけではわからないのである。

\section{6 固体のエネルギーバンド計算}

固体のエネルギーバンド計算も, 公開されているものが増 えてきた。計算規模が少し大きくなるが,パソコンでもでき るようになってきた。これはパソコンの性能の向上によると ころが大きい。

筆者の研究室では, 卒業研究で目崎君がOsaka2000 (現在は Osaka2002) という無償のバンド計算ソフトを用いて,Siやグラ ファイト,ナノチューブなどを計算した。Fig.2 (a) には, その 結果としてグラファイトの結果を示す。比較に過去の計算結 果をFig.2 (b) に示す。パソコンでもそこそこの計算ができる ことが理解できよう。

エネルギーバンド計算は, 密度汎関数法と平面波展開を併



(b)

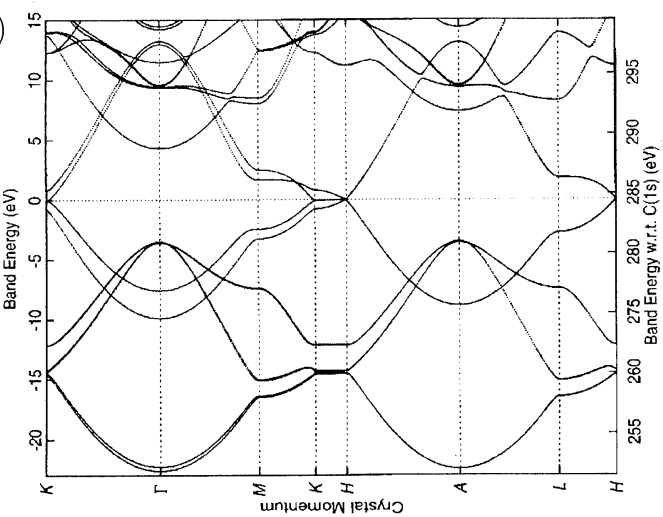

Fig.2 Energy band calculation of Graphite (a) with use of Osaka 2000 (T. Mesaki, graduating thesis 2003, the University of Electtro-Communications) and (b) by J. A. Carlisle et al. (Phys. Rev. B59 (1999) 7433). The original figure of $(b)$ is rotated here for comparison with (a).

用する手法が多く使われている。Osaka2000は計算原理を含 めたマニュアルもついているので, 独力でバンド計算までで きる。バンド計算をやってみたい人には是非㘯勧めしたい。 Webで検索すればすぐに場所がわかるはずである。このよう なソフトは, 多くの人の貢献によって成り立っている。無償 のソフトを使う場合には，その貢献に感謝し，できる範囲の協 力 (例えば入出力デー夕の公開, エラーの報告)をすることが 重要である。

\section{4. 物性量の計算}

電子状態を計算できると,そこから実験と直接比較できる 物理量を計算することができる。以下では代表的なものとし て振動計算, STM, 光吸収などを取り上げる。

\section{1 振動計算}

分子の振動モードや固体のフォノン構造を調べるには, 最 適化構造のまわりのポテンシャル関数の二階微分から力の定 数を決め, 運動方程式を解く。分子にN個の原子があれば, $3 \mathrm{~N}$ 個の座標の自由度がある。分子の場合にはこのうち3が重心 の並進運動, 3が重心の回りの回転運動であるから, 分子の振 
動の自由度は3N-6になる。また固体の場合には, 単位胞にN 個の原子があれば, $3 \mathrm{~N} か ゙$ 振動の自由度になる。

分子の振動計算は, MopacPGaussianには計算するプログ ラムが入っていて計算のキーワードをデー夕に追加するだけ で, 振動計算まで実行する。計算した結果としては, 固有振動 数や固有振動モードの方向, さらに赤外吸収強度などの結果 を得る。また分極関数を適当に指定することでラマン分光強 度も計算できる。このような結果は, 構造を仮定して得られ た結果であるので直接実験と比較することで, 未知の物質の 構造を同定することが可能である。

固体の振動モードも, Dynamic matrixという力の定数の行 列を計算することで任意の波数 きる。詳細は拙著, “Physical properties of carbon nanotubes”, (Imperial college press, London, 1998）を参照いただきたい。 非共鳴ラマン分光のスペクトルの計算法も記してある。

\section{2 状態密度と波動関数}

物質の性質, 物性を決めるものに電子の状態密度 (density of states, DOS）と波動関数がある。状態密度は, 電子がある エネルギーの中にどれくらい存在して, どれくらい占有する かを表した物理量であり，物質の㧍拉よその表情となってい る。状態密度は, 物質の色や光の吸收強度など光学的性質と 密接にかかわっている。電子のフェルミエネルギーでの状態 密度はNMRでのスピン密度, 輸送現象, さらに超伝導を代表 とする相転移現象に関連している。

低次元物質は, 状態密度に特異点 (状態密度またはその微分 が発散するエネルギー, ファンホーブ特異性という)があるこ とが知られ,顕著な物理現象が期待できる。例えば高温超伝導 体物質は二次元物質であり,ポリアセチレン, ナノチューブな どは一次元物質として知られ，それぞれ $\log \left|E-E_{0}\right|, 1 / \sqrt{E-E_{0}}$ で発散する。

物質中の特定の位置での状態密度を, 局所状態密度 (LDOS) という。操作プロープ顕微鏡 (SPM, 操作トンネル顕微鏡 (STM), 原子間力顕微鏡 (AFM) の総称名)の針を物質の一点 に固定して電圧を変化させ, 得られるスペクトルが操作トン ネル分光 (STS) である。この微分コンダクタンス (dI/dV) が 物質の局所状態密度と関係している。LDOSは直接実験と比 較できる量である。また, 原子軌道 $(1 \mathrm{~s}, 2 \mathrm{~s}, 2 \mathrm{p}, \ldots)$ の成分ご とに状態密度を計算したものを部分状態密度 (PDOS) とい う。この結果は, 直線偏光に対する吸収のスペクトルの偏光 特性を比較できる。

固体の局所状態密度や部分状態密度は, シュレンディガー 方程式を解いて得られる波動関数と固有エネルギーを $\mathrm{k}$ 空間 で積分して求められる。分子の場合には離散的な軌道エネル ギーであり, 状態密度はデル夕関数的になるが, 固有エネルギ 一を中心としてガウス関数として幅をもたせると, 固体の状 態密度と同じようなスペクトルが得られる。このときの幅の 值としては, 平均レベル間隔 $(0.01 \sim 0.1 \mathrm{eV})$ 程度がよい。こ
の幅は分子における周辺との相互作用であり，また電子状態 の寿命とも関係している。実験のスペクトルを再現するもの を選ぶとひとつの情報になる。

ある特定のエネルギーの波動関数の振幅を空間の関数とし て表示すると,おおまかな操作トンネル分光 (STM) の像を再 現することができる。ただLSTMの像は, STMの先端の針の 形状に大きく依存することがわかっているので, 計算と実験 が合っていても異なっていても気にすることはない。STM 像に特異な情報が含まれているか検討すべきである。

\section{3 光吸収}

光を吸収して電子が遷移するかどうかは, 電気双極子モー メントを始状態と終状態の波動関数で挟んで積分 (行列)す ればよい。電子状態計算で波動関数の形がわかっているので, 吸収スペクトルを計算することができる。量子化学計算では 光吸収まで計算できるものもある。簡便な方法として電子状 態の波動関数の対称性から光吸収の選択則を求め, 遷移可能 な状態間で結合状態密度 (JDOS) を求め, それを光の吸収久 ペクトルと比較する方法がある。結合状態密度には光の吸収 確率は計算できないが, スペクトルの同定には役に立つ。

分子軌道計算や固体のエネルギーバンド計算の電子の占有 していない状態は, 変分計算をした『残りカス』の部分である から, 固有エネルギーに終状態としての意味をもたせることは 原理的にできない。電子の遷移を計算で考えるのなら, 量子化 学では配置間相互作用 $(\mathrm{CI})$ 計算, また物理では準粒子の方法 などで励起エネルギーを計算すべきである。実は筆者はこの ことまで正確にいえる人間ではない。簡便な結果を使うとき に, そういう知識を覚えておいていただければ幸いである。

\section{5. 終わりに}

パソコンを使って電子状態計算をする一通りの手順を示し た。この文書だと, 宝の居場所を示した地図ぐらいの情報し かない。実際にお宝に出会えるかはなはだ心もとないと感じ られるかもしれない。しかし現在のソフトウエアは, 利用者 の利便性を考えて説明書などがくわしい。まずは使っていた だいて, そこから原理となる物理や化学に興味をもってくれ れば大変教育的であると思っている。単に物理や化学の原理 を理解するだけでなく, 実際の計算結果が出ることの驚きを 味わっていただき，さらに実験にも直接役に立つ研究室の道 具となることを期待している。

使った理論の結果を発表するときに, 専門の理論家が文句 を言ってくることが考えられる。計算をブラックボックスの ように使い, 結果を考慮せずに発表するというのが文句の内 容である。対策としては, 発表では結果の值をいう前に, どう いう手段で計算したかという説明を十分に行うことが必要で ある。また結果の妥当性を対照計算で示すのがよい。そうす れば, 専門の人もやり方に間違いがあれば, どういう点が問題 であり,どうすればよいか指摘することができる。学会など 
は良い機会なので, 批判する人間を捕まえていろいろ教わっ たらよいと思う。

本稿が何らかの研究の動機になり, また理論と実験との共 同研究の芽となることを願っている。

\section{謝 辞}

本研究は, 東北大A. Grueneis, 目崎 高志, MIT G. Dresselhaus, M. S. Dresselhaus, UFMG, UFC (ブラジル)のA. Jorio, A. G. Souza Filho, M. A. Pimentaほか, 多くの人との共同研究の成
果である。本稿に関する研究の一部は, 文部科学省科学研究 費 (No.13440091) による成果である。

\section{文 献}

1) Jian Ping Lu, et al, Phys. Rev. Lett. 68 (1992) 1551.

2) O. L. Blakslee, D. G. Proctor, E. J. Seldin, G. B. Spence and T. Weng, J. Appl. Phys. 41 (1977) 3373-3382.

3) 岡田 晋, 東京工業大学博士論文 (1997).

4) J. Tersoff, Phys. Rev. B 37 (1988) 6991.

5) R. Saito, R. Matsuo, T. Kimura, G. Dresselhaus and M. S. Dresselhaus, Chem. Phys. Lett. 348 (2001) 187-193. 